Article

\title{
DInSAR for a Regional Inventory of Active Rock Glaciers in the Dry Andes Mountains of Argentina and Chile with Sentinel-1 Data
}

\author{
Cristian Daniel Villarroel ${ }^{1, *}$, Guillermo Tamburini Beliveau ${ }^{2}$ (D), Ana Paula Forte ${ }^{3}$ (D), \\ Oriol Monserrat ${ }^{4}$ and Monica Morvillo ${ }^{5}$
}

1 Faculty of Exact, Physical and Natural Sciences (FCEFyN), Department of Geology, Av. Jose Ignacio de la Roza Oeste 590, National Council of Scientific and Technical Research (CONICET) National University of San Juan (UNSJ), San Juan 5400, Argentina

2 School of Surveying, National University of Rosario, Pellegrini 250, Rosario 2000, Argentina; guillermo.tamburini@e-campus.uab.cat

3 National Council of Scientific and Technical Research (CONICET) - National University of San Juan (UNSJ), Center of the Geosphere and Biosphere Research (CIGEOBIO), Av. Jose Ignacio de la Roza Oeste 590, San Juan 5400, Argentina; anapau.forte@gmail.com

4 Technological Center of Telecommunications of Catalonia (CTTC), Geomatic Area, Av. Gauss 7, E-08860 Castelldefels, Barcelona, Spain; oriol.monserrat@cttc.cat

5 Faculty of Exact, Physical and Natural Sciences (FCEFyN), Department of Geology, National University of San Juan (UNSJ), Av. Jose Ignacio de la Roza Oeste 590, San Juan 5400, Argentina; mmorvillo@hotmail.com

* Correspondence: cristian.villarroel@unsj-cuim.edu.ar; Tel.: +549-264-4234129

Received: 8 August 2018; Accepted: 2 October 2018; Published: 3 October 2018

\begin{abstract}
The Dry Andes region of Argentina and Chile is characterized by a highly developed periglacial environment. In these arid or semi-arid regions, rock glaciers represent one of the main pieces of evidence of mountain creeping permafrost and water reserves in a solid state. However, their distribution, degree of activity, and response to global warming are not yet well understood. In this context, this work aims to show the potential of the Sentinel-1-based interferometric technique (DInSAR) to map active rock glaciers at a regional level. In particular, the paper presents an active rock glacier inventory for the study area, which covers approximately $40,000 \mathrm{~km}^{2}$, ranging from latitude $30^{\circ} 21^{\prime} \mathrm{S}$ to $33^{\circ} 21^{\prime} \mathrm{S}$. A total of 2116 active rock glaciers have been detected, and their elevations show a high correlation with the west-east direction. This result was obtained by using only 16 interferometric pairs. Compared to other remote sensing classification techniques, the interferometric technique offers a means to measure surface displacement (active rock glacier). This results in a reliable classification of the degree of activity compared to other methods, based on geomorphological, geomorphometric, and/or ecological criteria. This work presents evidence of this aspect by comparing the obtained results with existing optical data-based inventories. We conclude that the combination of both types of sensors (radar and optical) is an appropriate procedure for active rock glacier inventories, as both mapping methodologies are complementary.
\end{abstract}

Keywords: DInSAR; Sentinel 1; rock glacier inventories; mountain permafrost; Dry Andes

\section{Introduction}

In recent decades, aerial photos or satellite optical images have been the most common tools used to generate regional inventories of rock glaciers [1-4]. Nowadays, the advent of SAR-based satellites and the use of interferometric techniques enable the objective identification of active rock glaciers and 
quantification of their movement [5-8]. This is a complementary and powerful tool to improve the reliability of the existing inventories [5]. This work aims to demonstrate the potential of the relatively new Sentinel-1 SAR constellation for this purpose. In particular, Sentinel-1 interferometry is used in the Dry Andes region to obtain a regional inventory of active rock glaciers.

Several regional inventories based on optical data [1-4] can be found for the Dry Andes region. Such inventories have two main limitations. First, the presence of clouds, shadow areas, and snow represents an important constraint for both the completeness and the reliability of the inventory [5]. Second, assessment of the degree of activity in these types of inventories is usually based on geomorphological criteria. This approach is qualitative, subjective, and, as can be seen in the papers of Roer and Nyenhuis and in the Master's thesis of Azócar [9,10], has a greater relevance in the discrimination between active rock glaciers and relict rock glaciers than in discerning between active and inactive.

These limitations can be partially resolved by the Synthetic Aperture Radar Differential Interferometry (DInSAR) technique, which has been widely used in different regions to identify and quantify movements of these periglacial environment landforms [5-8]. It provides objective information on the existence of movement, which is one of the main potentialities of the technique. Moreover, the DInSAR technique allows the detection of slow superficial movements that define the limit between active and inactive rock glaciers [9]. In this work, we have considered $2.2 \mathrm{~cm} /$ year as a threshold to discriminate between active and non-active rock glaciers. A more detailed classification of landforms as a function of movement rates applied in the Swiss Alps is described in [11].

The phase difference between two backscattered SAR echoes of the same area on the ground taken at slightly different view angles can be used to detect small surface changes in the order of a few centimeters [12]. This technique is known as differential SAR interferometry (DInSAR) and has been shown to successfully detect surface displacements in the radar line-of-sight caused by mass movements in alpine terrain [13]. Some studies on rock glacier deformation suggest that the technique could also be promising for relatively small objects in mountainous terrain [14-16].

The DInSAR technique has been used previously to detect active rock glaciers in different regions. Wang et al. [5] used SAR interferometry and optical data to map and quantify the movement of 261 rock glaciers in the northern Tien Shan of China. Barboux et al. [11] provided a set of recommendations for the use of DInSAR in mountainous areas. They also provided an extensive landform inventory of the western Swiss Alps, including rock glaciers, landslides, and push-moraines. Another example is the work by Lilleoren et al. [17], who used a detailed inventory of landforms related to permafrost (rock glaciers and stable ice-cored moraines) to define the past and present limits in altitude of the alpine permafrost. In this case, DInSAR was used to validate the classification of active landforms by means of geomorphological analysis. In Liu et al. [8], the InSAR technique was used to map 59 rock glaciers in Sierra Nevada, California. Finally, several studies have focused directly on the dynamics of one or several rock-glaciers $[12,15,18,19]$.

The DInSAR technique can objectively and reliably solve some limitations of optical data: it works in the presence of clouds, and is also able to do so in the presence of snow, providing information on the activity level of the analyzed landform. However, there are some limitations that must be taken into account. The first is that it does not provide an exhaustive inventory. DInSAR provides Line of Sight (LOS) measurements, i.e., it measures the projection in the satellite-object line of the real displacement. This results in a negligible sensitivity to displacements perpendicular to the LOS, more or less in the North-South direction. The second limitation is SAR geometry. The visibility of a given landform depends on the slope and the aspect. Therefore, in any given satellite trajectory, there will be landforms that are not visible. However, this can be relatively solved by using the ascending and descending satellite trajectories. The last limitation is related to the sensitivity to minimum and maximum displacements. However, this limitation can be partially solved by using the multi-temporal analysis of interferometric 
pairs. Considering the advantages and limitations described above, the need to integrate optical and SAR data to provide exhaustive and reliable regional rock glacier inventories is worth noting.

The region of the Central Andes (Southern Dry Andes) (Figure 1) has one of the densest concentrations of rock glaciers in the world [20]. Rock glaciers constitute some of the most significant evidence of mountain permafrost. They are lobate-to-tongue-shaped bodies of permanently supersaturated frozen detrital material with interstitial ice, ice lenses, and massive ice. In an active state, they are characterized by a downslope cohesive flow movement due to their ice content. The moving velocities range from a few centimetres to several meters per year. An inactive state implies that they have no movement, though they still contain frozen material [21,22]. However, despite the climatic, paleoclimatic, mass wasting, and hydrological significance of these landforms in arid and semi-arid regions [23-25], their spatial distribution and dynamics are still not well known. This is particularly critical in the Dry Andes, where there are still areas for which there is no inventory of these landforms. In addition, surveys on surface dynamics are almost non-existent [26,27]. This is a key issue that affects the development of populations located in the basins of these regions, where the water resources, necessary for human consumption and productive activities, are driven by cryogenic processes.

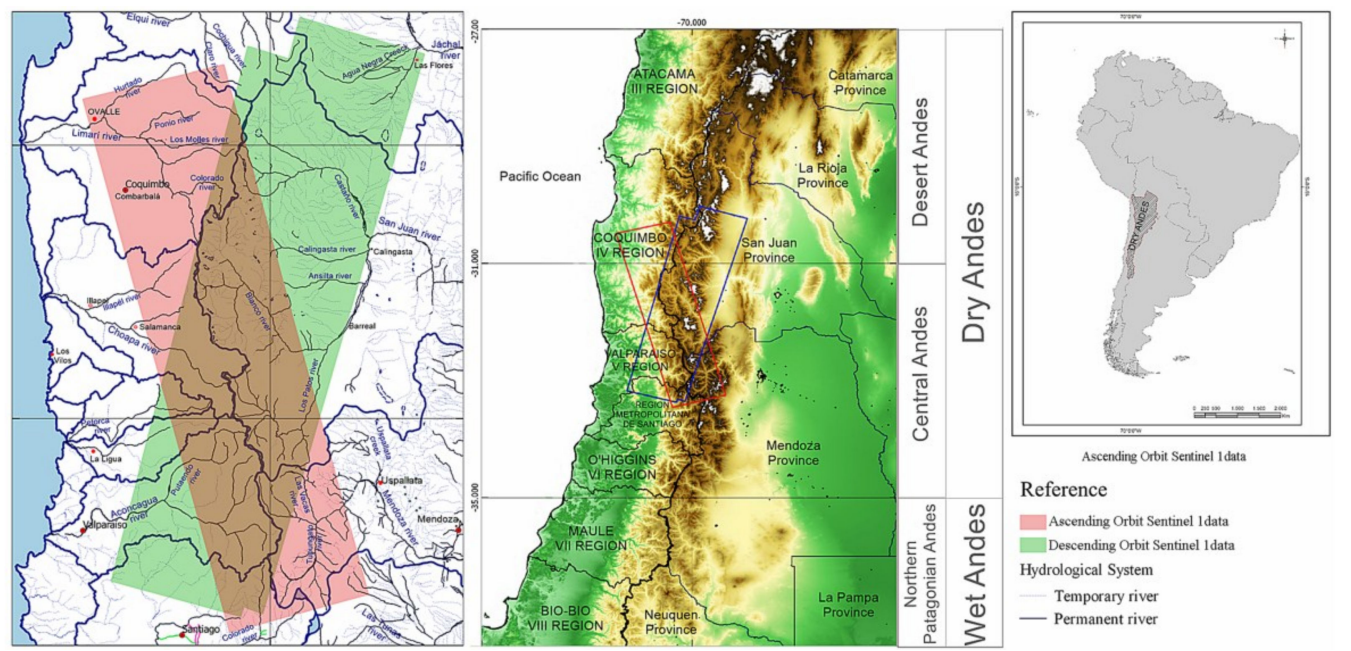

Figure 1. Location of the study area. (a) Main river basins, cities, and area covered by ascending and descending orbit Sentinel-1 data. (b) Provinces and regions in the Dry Andes of Argentina and Chile. (c) Regional location of the Dry Andes in South America.

\section{Study Area}

The Dry Andes in Argentina and Chile are located from $35^{\circ} \mathrm{S}$ to the north in the Andes Mountains. The $31^{\circ} \mathrm{S}$ latitude is the glaciological-climatological limit between the Desert Andes to the north and the Central Andes to the south (Figure 1).

The Desert Andes are characterized by the presence of small glaciers or glacieretes, perennial snow patches, and arid climates with low rates of precipitation and high values of potential solar radiation. The Central Andes are characterized by semi-arid climates with larger glaciers, and greater precipitation and elevation values [28]. These high mountain regions, with extreme spatial variability of the surface and subsurface properties and characteristics [29], present wide mountain permafrost development $[1,30]$. Permafrost is distributed irregularly due to the spatial variability of the thermal regime of the subsoil.

The present work was carried out between $30^{\circ} 21^{\prime}$ and $33^{\circ} 21^{\prime}$ south latitude, covering a total area of approximately $40,000 \mathrm{~km}^{2}$. This area includes the headwaters of the most important water systems in these latitudes of Argentina and Chile: in Argentina, the basins of the Mendoza River, the San Juan River, and the southern sector of the Jáchal River basin; and in Chile, the basins of the Limari, Choapa, and Aconcagua rivers and the northern sector of the Maipo river basin (Figure 1). 
The area studied in Argentina ranges from the central-north region of the province of Mendoza to the central-south region of the province of San Juan. The two provinces have a combined population of 2.6 million people [31]. In Chile, it covers the central-south sector of the VI region, the entirety of the $\mathrm{V}$ region, and the northern sector of the Santiago metropolitan area. These regions have a population of approximately 9.9 million inhabitants, which is 53\% of Chile's total [32].

On both sides of the mountain range, the population depends on the water resources originating from the high-lying mountain area, with glacial and periglacial environments as the main sources [33-37]. The monitoring of these water sources is a key activity for these regions due to the scarcity of water resources, aggravated by the growing water demand for agricultural, industrial, urban, and hydroelectric use [38-41]. Satellite snow monitoring [42] and artificial lakes for water storage [43] are two techniques that the Chilean government (DGA-General Directorate of Water) have implemented for water supply management.

\section{Climate Setting}

The subtropical South Pacific anticyclone, where the dry air high-pressure belt reaches the continent at south latitude $31^{\circ}$ [44], is the main driver behind the climate of the Dry Andes. It is characterized by arid to semi-arid climates, with low precipitation values, relative humidity, and cloudiness. This results in high solar radiation and terrestrial surfaces with very low percentages of vegetation and humidity. In both Argentina and Chile, year-to-year precipitation varies notably in accordance with the El Niño or ENSO (El Niño Southern Oscillation) phenomenon [45-47]. This aspect directly affects the region's runoff water [48,49].

The topography and coastal position of the Andes mountain range have a strong influence on the general atmospheric circulation, notably differentiating the eastern and western climatic systems [50,51]. Moist air masses of the Pacific Ocean rise through the Andes orography, which acts as a barrier to moisture transfer [52]. For this reason, the water reserves that supply the surrounding regions are concentrated in the mountain ranges, with precipitations being higher in the western than in the eastern sector. It is worth mentioning that the Argentinian side of the study area has the highest elevations in the American continent, namely Mount Aconcagua (6962 m.a.s.l.) and Cerro Mercedario (6770 m.a.s.1.) (Figure 1). The southern winds predominate on the western flank of the Andes, while on the eastern slope, the winds blow mainly from the north [53]. According to Gascoin et al. [36] in the Central Andes, the precipitation coming from the humid Pacific masses occurs almost exclusively as snowfall and is mostly concentrated in the austral winter, between the months of May and August. Moreover, the eastern sector is also influenced by wet Atlantic air masses from the southeast [53]. This arid situation is accompanied by intense solar radiation, which in the Dry Andes, has an annual average of $400 \mathrm{w} / \mathrm{m}^{2}$. Schrott [54] discusses the influence of solar radiation on the processes of fusion and on the soil temperature in the area. The special climate conditions of the area make the DInSAR technique a suitable tool for the target study of this work.

Recent climatic records show a trend of rising temperatures in the Central Andes. Between 1979 and 2006, the average temperature of the air has risen between $0.2{ }^{\circ} \mathrm{C}$ and $0.4{ }^{\circ} \mathrm{C}$ per decade [55]. Poblete and Minetti [56] indicate that this warming is related to the decrease in the snowfalls that supply the Central Andes basins. This situation is more evident with the retreat and mass loss of glaciers in the basins of both Chile and Argentina since the beginning of the twentieth century $[35,57]$.

The precipitation in the Dry Andes ( $27^{\circ}$ and $33^{\circ}$ lat. south and 3000-4000 m.a.s.1.) varies between $200 \mathrm{~mm} /$ year in the northern sector and 700-800 mm/year in the south. Precipitation increases during El Niño periods and decreases during La Niña. Meanwhile, the $0{ }^{\circ} \mathrm{C}$ isotherm of the MAAT increases in height from 3700 m.a.s.l. in the south up to 4300 m.a.s.l. in the north [58].

As a first approximation order, MAAT can be used to delimit mountainous regions and altitudinal belts with the occurrence of permafrost. MAAT below $-3{ }^{\circ} \mathrm{C}$ indicates areas with a significant amount of permafrost, while only a few occurrences of permafrost exist around $-1{ }^{\circ} \mathrm{C}$ [59]. 


\section{Dataset and Methodology}

In this work, active landforms associated with periglacial dynamics have been identified and inventoried using the DInSAR technique with Sentinel-1 data in combination with optical data (Spot images) [5,60,61]. The Sentinel-1 differential interferograms were used to detect active areas. Later, they were classified according to landform type with the support of optical images from the 6 and 7 SPOT satellites. The obtained inventory was then compared with previous inventories made using optical images and based on geomorphological criteria to establish the degree of activity of the landforms. Last, a statistical analysis was carried out to evaluate the influence of topographical characteristics (sites and elevations) on rock glacier behavior.

\subsection{Sentinel-1 DInSAR Applied to Dry Andes}

The Sentinel-1 is a two-satellite constellation of the European Space Agency (ESA). The first satellite, Sentinel-1A, was launched in April 2014 and the second, Sentinel-1B, in April 2016. Compared to older constellations, Sentinel- 1 offers remarkable features that have notably widened the applications of SAR interferometry $[62,63]$. Chiefly, Sentinel-1 assures continuity in worldwide acquisitions, with a revisit time varying between six and 24 days, depending on the place. Additionally the orbital tube has a diameter of $300 \mathrm{~m}$, minimizing the baselines between images and hence, providing less noisy interferograms compared to other sensors like Envisat, ERS, and Cosmo-SkyMed. Finally, the Sentinel-1 data is freely available without any restrictions for use. These characteristics result in a reliable system that has changed the DInSAR paradigm, providing a new and powerful tool for monitoring purposes.

Differential SAR interferometry consists of the exploitation of the phase differences between two SAR images of the same area acquired at different times or from slightly different positions [64]. The interferometric phase is directly related to the differences in the satellite-target travel of the radar signal. These differences include the movements of the target between both acquisitions. However, the identification of these movements is not always a straightforward process. The phase is also affected by other components, such as the differences in the weather conditions at the acquisition times, the distance between the acquisition positions, or noise. Moreover, it must be taken into account that the phase values are known modulus $2 \pi$, i.e., the real phase differences are wrapped in the interval $[-\pi, \pi]$. The process of recovering the real values of the phase, called phase unwrapping, is an ill-posed problem. This aspect limits the ability to measure relatively fast movements $(1 \mathrm{~m} /$ year). This is key to interpreting the DInSAR data properly for displacement detection.

The relation between phase difference and displacement is proportional to the wavelength of the SAR signal. A phase variation of $2 \pi$ between pixels of the interferogram corresponds to half a wavelength of relative displacement between the corresponding points on the ground [64]. In the case of Sentinel-1, which operates in C-band, this is equivalent to $2.8 \mathrm{~cm}$. However, the displacements measured by DInSAR are always in line of sight (LOS), i.e., it measures the projection of the real displacement in the sensor-target line. This means that the real displacements are usually underestimated. Under favorable conditions of low atmospheric components and noise, it is possible to measure displacement between points up to one tenth or less of the wavelength. This corresponds to approximately $3 \mathrm{~mm}$ of LOS displacement [61]. In this work, we analyze the interferograms with short temporal baselines $(6,12,24$, and 48 days). This is done in order to maintain high coherence and thereby maximize the covered areas. Table 1 shows the minimum displacement rate that is detectable for these temporal baselines. For example, the minimum detectable movement in a six-day interferogram is approximately $17 \mathrm{~cm} /$ year, while in a 48-day interferogram, it is $2.2 \mathrm{~cm} /$ year. It is worth noting that these numbers must be taken as an approximation and they can change as a function of coherence and noise level. 
Table 1. Rough estimation of the minimum displacement rate in an interferogram as a function of the temporal baseline for the C-Band of Sentinel 1.

\begin{tabular}{ccc}
\hline Temporal Baseline [Days] & $\begin{array}{c}\text { Minimum Detectable } \\
\text { Displacement [cm/Year] }\end{array}$ & $\begin{array}{c}\text { Maximum Detectable } \\
\text { Displacement [cm/Year] }\end{array}$ \\
\hline 6 & 17 & 170 \\
12 & 8.5 & 85.2 \\
24 & 4.2 & 42.6 \\
36 & 2.9 & 28.4 \\
48 & 2.2 & 21.3 \\
\hline
\end{tabular}

Establishing a maximum observable displacement value is a more complex task. The main reason for this is that it not only depends on the wavelength, but also on the random characteristics of the movement and terrain. However, a rough approximation can be arrived at by assuming that the maximum detectable movement is below half a wavelength $(2.8 \mathrm{~cm}$ for Sentinel-1). This corresponds to $170 \mathrm{~cm} /$ year for the six-day interferograms to $21.3 \mathrm{~cm} /$ year for the 48 -day readings. This work focuses on the detection of active periglacial phenomena, and not on the determination of their magnitude of displacement. Therefore, the range of detectable displacement, from $2.2 \mathrm{~cm} /$ year to $170 \mathrm{~cm} /$ year, almost covers the entire displacement values recorded in the literature for the observed phenomena $[5,10,19]$. In particular, rock glaciers do not exceed point displacements of more than $300-400 \mathrm{~cm} /$ year [22]. Maximum values are typically lower than $100 \mathrm{~cm} /$ year.

The dataset used consisted of all possible interferometric pairs covering the selected area with temporal baselines of less than 48 days. The acquisition period ranges from October 2014 to April 2017, containing up to two hundred available images distributed in four orbital trajectories, two ascending and two descending. The images used were acquired in Interferometric Wide swath (IW) mode with polarity VV. The final set of selected interferograms consisted of eleven interferograms in the austral summer of 2014 and 2016 (December/March), three in the autumn/winter of 2015 (April/July), and two in the autumn of 2017 (April), as shown in Table 2. Each interferogram consisted of two entire Sentinel-1 frames. The off-nadir angles covered the entire spectrum available for the standard IW mode of this sensor, between $33^{\circ}$ and $48^{\circ}$ [65].

The interferograms were generated and unwrapped using the software developed by the Geomatics Division of the CTTC (Technological Center and Telecommunications of Catalonia) [66]. The 1 arc-second (about 30-m) resolution SRTM (Shuttle Radar Topography Mission) [67] was used to remove the topographic contribution to the phase of the interferograms. The final interferograms were generated using a multilook of five pixels in range to reduce the level of noise. The large number of processed images enabled researchers to choose interferometric pairs of high quality in terms of coherence or noise. The atmospheric component is not a critical issue in this work, since the maximum dimensions of the objects observed (less than $2 \mathrm{~km}^{2}$ ) are small enough to have a significant contribution from the atmospheric phase component. Moreover, since the focus is not on the magnitude of the deformations, the moderate presence of any source of systematic errors, such as atmosphere, does not affect the interpretation of the results. The final resolution of the interferograms is approximately $15 \mathrm{~m}$ and the minimum area of motion detection was defined in 2 ha.

The inaccuracy of the Digital Elevation Model (DEM) used to determine the topographic component is another possible source of error $\left(\sigma_{\mathrm{DEM}}\right)$. The effects of $\sigma_{\mathrm{DEM}}$ in the interferometric phase are proportional to the distance between the satellite position at different acquisition times [63]. However, as commented on above in this document, the Sentinel- 1 constellation orbits are in a 300 hundred m-diameter tube, which assures a low sensitivity to DEM errors. In particular, for our dataset, the worst perpendicular baseline is $65 \mathrm{~m}$, which in the case of low noise, means a maximum probable DEM error of $15 \mathrm{~m}$. 
Table 2. Generated interferometric pairs.

\begin{tabular}{|c|c|c|c|}
\hline Master Image Date & Slave Image Date & Temporal Baseline [Days] & Perpendicular Baseline \\
\hline \multicolumn{4}{|c|}{ Ascending 1} \\
\hline 4 April 2015 & 28 April 2015 & 24 & 14 \\
\hline 17 Januarty 2016 & 10 February 2016 & 24 & -32 \\
\hline 10 February 2016 & 5 March 2016 & 24 & -52 \\
\hline 5 March 2016 & 29 March 2016 & 24 & 61 \\
\hline 29 April 2017 & 5 May 2017 & 6 & -51 \\
\hline \multicolumn{4}{|c|}{ Ascending 2} \\
\hline 12 December 2014 & 5 Janury 2015 & 24 & 37 \\
\hline 5 May 2015 & 22 June 2015 & 48 & 65 \\
\hline 31 December 2015 & 24 January 2016 & 24 & 14 \\
\hline 24 January 2016 & 17 February 2016 & 24 & 32 \\
\hline 17 February 2016 & 12 March 2016 & 24 & 26 \\
\hline \multicolumn{4}{|c|}{ Descending 1} \\
\hline 15 January 2016 & 3 March 2016 & 48 & 46 \\
\hline 3 March 2016 & 27 March 2016 & 24 & -12 \\
\hline \multicolumn{4}{|c|}{ Descending 2} \\
\hline 8 June 2015 & 2 July 2015 & 24 & -57 \\
\hline 15 February 2016 & 27 February 2016 & 12 & 16 \\
\hline 27 February 2016 & 22 March 2016 & 24 & -43 \\
\hline 4 April 2017 & 16 April 2017 & 12 & -25 \\
\hline
\end{tabular}

\subsection{Active Landforms Detection with DInSAR}

The identification of active landforms has been done by the visual interpretation of wrapped and unwrapped interferograms. The former makes it possible for researchers to identify the deformation phenomena; however, in some cases, the latter can help improve the interpretation of the movement. Figure 2 features some examples of the identification of different active landforms.

The detection of the active landform patterns in the interferograms was performed in satellite geometry. Once the patterns were identified, they were geocoded in order to locate their position on the ground. Then, the discrimination between rock glaciers and other landforms was achieved using optical images acquired by the satellites SPOT 6 and 7, provided by the Argentinian National Commission of Spatial Activities (CONAE). This step was necessary because there were different processes and landforms present in the region (debris-covered glacier, protalus rampart, landslide, etc.), with movement rates similar to those of the active rock glaciers. In particular, debris-covered glaciers sometimes show interferometric patterns that are very similar to those of rock glaciers (see Figure 2). To avoid misclassification, different morphological criteria were considered in the optical images (present or past glacier presence, U-shaped valley, presence of extensional cracks, abundance of thermokarst, surface roughness, and material organization) to identify debris-covered glaciers. An increase in the debris/ice ratio leads to the evolution of glaciers in debris-covered glaciers and finally in rock glaciers. This morphological change between a debris-covered glacier and rock glacier usually implies a change in the movement rate. The flow of debris-covered glaciers is very similar to glaciers, while rock glaciers have greater internal deformation (and very irregular surface morphology), leading to a more viscous flow and lower speeds. Occasionally, this is detectable in the interferograms, because the upper part (debris-covered glacier) could show decorrelation (due to the higher speed) and the lower part (rock glacier), a clear pattern of movement. In these cases, both the dynamic and geomorphological criteria have been used to establish the boundary between both units. 

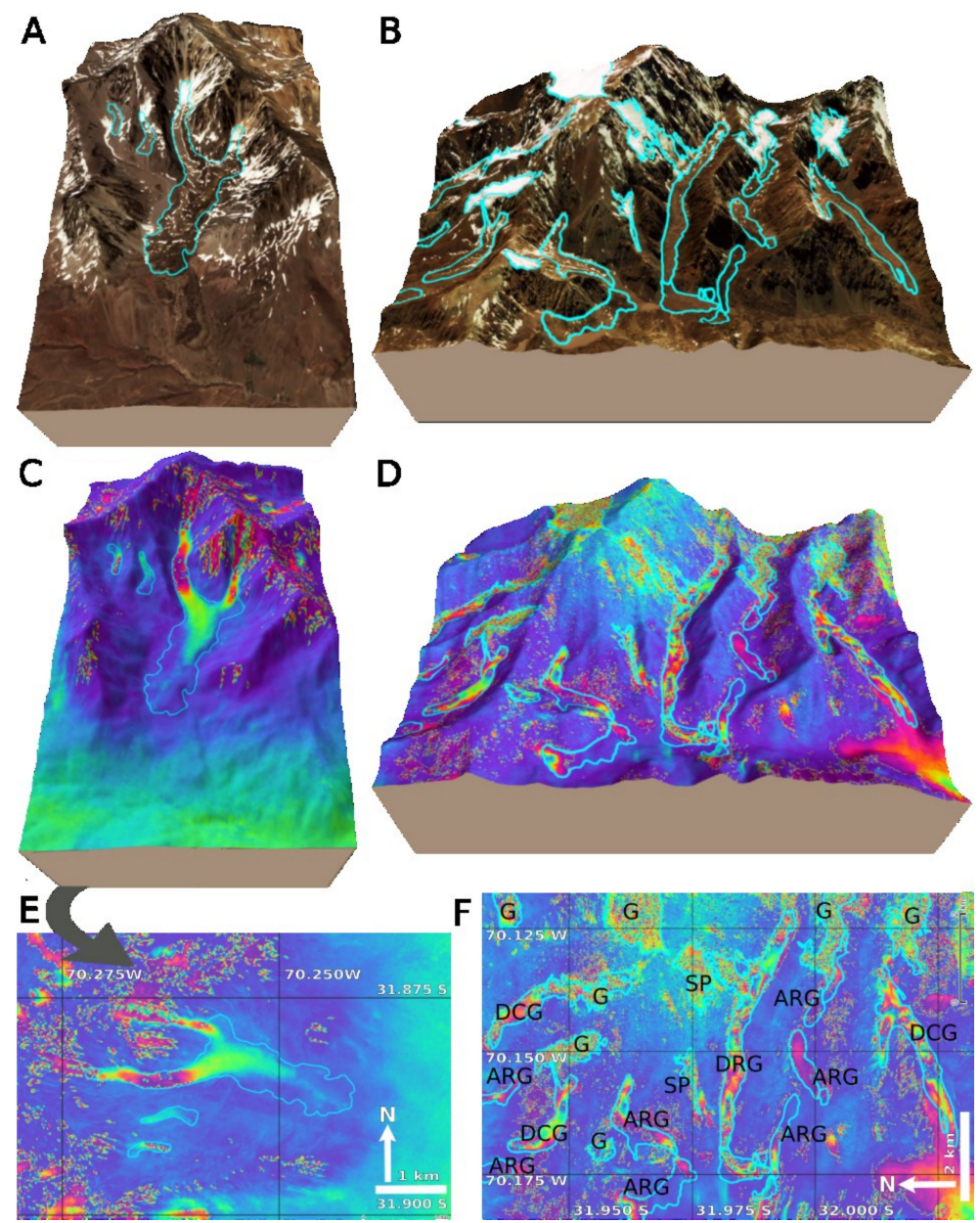

Figure 2. Identification and classification of different landforms detected in two different interferograms covering the area of the El Gigante rock glacier (A) and the western area of Cordon de La Ramada (B). The acronym meanings are: ARG: Active Rock Glacier; DCG: Debris-Covered Glacier; G: Glacier; SP: Snowpatch. (C,D) show the interferograms superimposed on a 3D terrain. (E,F) show the interferograms in 2D. Light blue polygons belong to the National Glacier Inventory (NGI).

On the other hand, some protalus ramparts, considered as a small phenomenon of the permafrost creep [68], have also been recognized. In this case, the identification was done though geomorphological criteria, such as location with respect to the hillside, wide/long relation, and the development of furrows and ridges. The entire inventory of active rock glaciers was prepared in an open-source GIS environment QGIS [69]. The active rock glaciers detected in the interferograms were manually located with a point located in the central area of the area they cover. The corresponding elevation was determined by means of the SRTM DEM, considering the height of the central point.

Figure 2 shows several examples of pattern detection and classification of different landforms. Figure 2A shows a SPOT optical image projected onto a 3D model of the covered area (above) and a six-day interferogram (middle and bottom) of the same area. In this example, the detected patterns correspond to "El Gigante" rock glacier $\left(31^{\circ} 52^{\prime} 57^{\prime \prime} \mathrm{S}, 70^{\circ} 15^{\prime} 12: 5^{\prime \prime} \mathrm{W}\right)$, which is a complex, multi-lobe, and multi-root rock glacier with a complex origin and different states of activity along different ages. It can be observed that only the upper lobes show activity. This indicates that the lower lobes have lower movement rates, which is confirmed by 24-day interferograms. Figure 2D shows a 12-day wrapped interferogram of the west part of the Cordón de La Ramada area $\left(31^{\circ} 59^{\prime} 02: 50^{\prime \prime} \mathrm{S}\right.$, $70^{\circ} 80^{\prime} 44: 50^{\prime \prime} \mathrm{W}$ ). In this example, different active landforms with different degrees of phase decorrelation (in most cases indicating different degrees of activity) are identified. It can be observed that glaciers 
and snow patches show higher decorrelation, while rock glaciers and debris-covered glaciers show well-defined movement patterns.

\subsection{Comparison of DInSAR and Optical Based Inventories}

The obtained inventory was compared to the available Argentinian National Glacier Inventory (NGI, www.glaciaresargentinos.gob.ar). The NGI was created by the Argentine Institute of Nivology, Glaciology and environmental sciences (IANIGLA-CCT, Mendoza) using optical images. The number of inventoried landforms and the degree of activity attributed to them were compared. The NGI includes the debris-covered glacier-rock glacier category as a landform type. The main reason for this is that sometimes it is difficult to separate both landforms using only the visual analysis of satellite images. Therefore, to perform the inventory comparison, both the active rock glacier category and the debris-covered glacier-rock glacier category have been considered. The same comparison was not possible for the Chilean side because the available inventories do not include the degree of activity in their classification (General Water Directorate, http:/ / www.geoportal.cl) or do not contain information about the landform area [1].

\subsection{Statistical Analysis}

The aim of this section is to use a statistical approach to detect and evaluate the spatial autocorrelation of the elevations of the rock glaciers, considering the global geographic domain and separation by basins. As a first step to analyze the influence of the spatial factor on the elevations of rock glaciers, the variance analysis technique (ANOVA) was applied. This technique supports the equality of the means of elevations in the set of basins, under the assumptions of normality and homoscedasticity.

Spatial autocorrelation is the distinctive assumption of spatial statistics and is defined as the tendency of the variable to take increasingly similar values in closer and closer places, separated by a distance (h). This property is measured and parameterized with the semi-variogram function, $\gamma(h)=\frac{1}{2} E\left\{[V(s+h)-V(s)]^{2}\right\}:$ where, $\mathrm{E}=$ Expected value; $\mathrm{V}=$ Variable (elevation); $\mathrm{s}=$ Site $(\mathrm{X}, \mathrm{Y})$; and $\mathrm{h}=$ Distance between two sites (s).

Spatial autocorrelation is validated by the increasing behavior of the semi-variogram function $\gamma(h)$, from a minimum observed distance to a limit range $(\mathrm{h}=\phi)$. This function also shows directions of greater or lesser influence (anisotropy) based on a discriminated calculation in the directions $0^{\circ}, 45^{\circ}, 90^{\circ}$, and $135^{\circ}$.

One limitation in calculating the semi-variogram is that it requires the variable to be stationary, i.e., its average does not vary or does not depend on the site, $E[V(s+h)]=E[V(s)]=\mu$.

This requirement does not imply a restriction since, in the case of non-stationary variables, the structural model consisting of the sum of the global spatial tendency $\mu(s)$ and a stationary residual variable $\delta(s)$ is considered:

$$
V(s)=\mu(s)+\delta(s)
$$

With $\mu(s)=E[V(s)]$ as the global trend in the entire geographic domain, which is parameterized in a polynomial function of degree 0,1 , or 2 in the site coordinates, $s=(x, y)$, representing a plane with and without a slope or a curved surface, and $\delta(s)$ as the stationary residual variable with zero mean and spatial autocorrelation measured by $\gamma_{\delta}(h)$. This approach was used to conduct the structural analysis.

\section{Results}

A total of 2116 active rock glaciers were detected in the study area (Figure 3). The majority (1629 glaciers or $77 \%$ of the total) are distributed between the south-central sector of San Juan province and the northern sector of Mendoza province. In particular, they cover the basins of the Castaño, Calingasta, Ansilta, Blanco, and Los Patos rivers of the San Juan River water system; the basin of the Rio Blanco Inferior, which is part of the Jachal river water system; and the Cuevas-Vacas and Tupungato river basins of the Mendoza River water system. The rest, on the Chilean side, are divided between the centre-south 
sector of Region IV, Region V, and the northern sector of the Metropolitan Region, distributed between the basins of the Limarí, Choapa, Aconcagua, and northern sectors of the Maipo river basin.

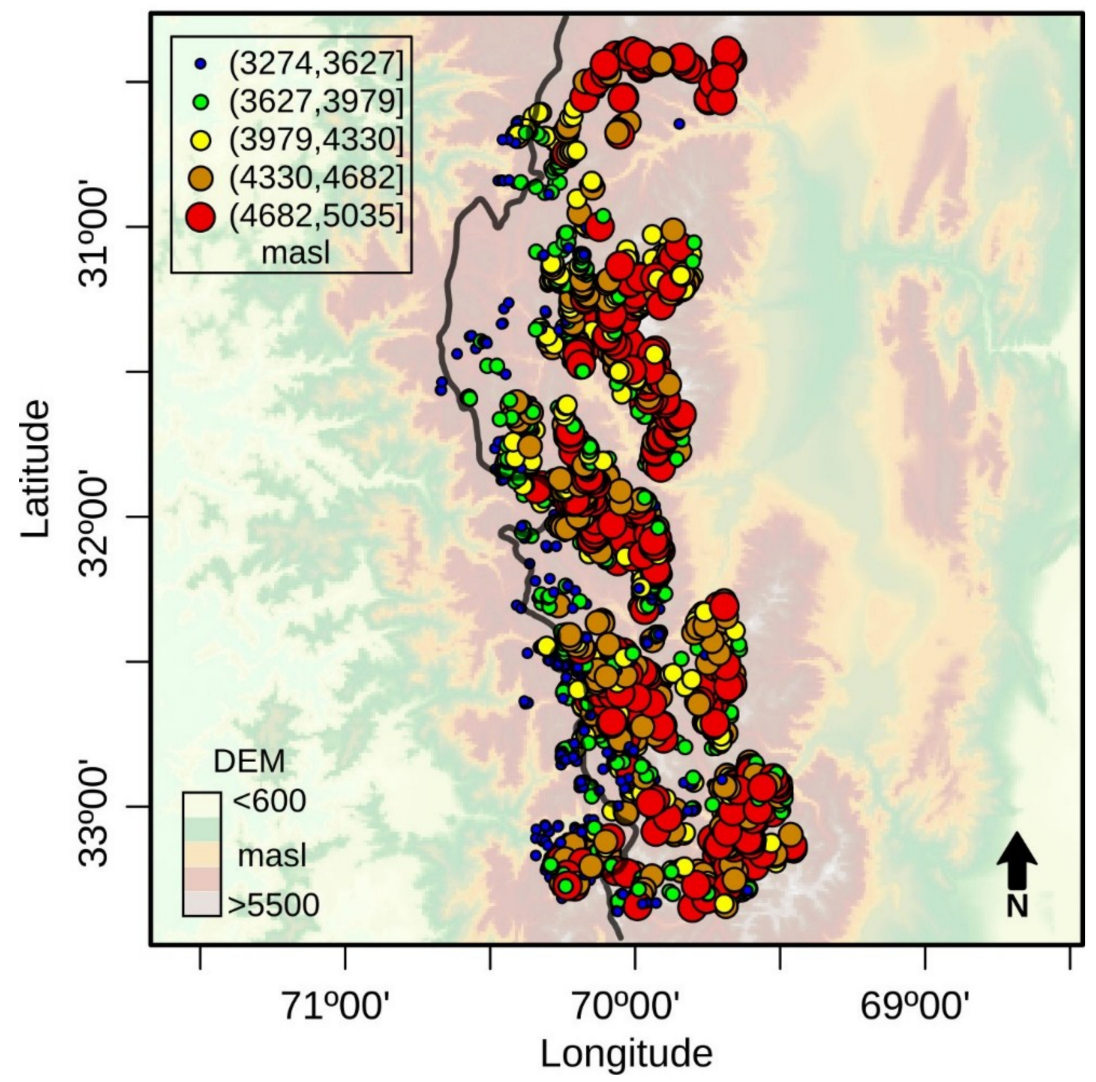

Figure 3. Map of spatio-altitude distribution of active rock glaciers. The black line indicates the national borders.

Two main characteristics of the active rock glaciers can be easily observed from the results (Figure 3). First, there is a noticeable increase of active rock glaciers towards the south. Second, their altitude increases towards the east. The mean altitude in the west is around 3300 m.a.s.l., while in the center-east sector, it is approximately 5000 m.a.s.l.

\subsection{Comparison between DInSAR and Optical Inventories}

The two methodologies could be compared in seven sub-basins (Castaño, Calingasta, Ansilta, Blanco, Los Patos, Cuevas-Vacas, and Tupungato), where the details of the optical rock glacier inventories are available. In order to improve the comparison between both methods, all of the bodies with areas below 2 ha (the minimum value captured by the DInSAR methodology) were filtered from the optical inventory.

Table 3 summarizes the main figures from the comparison of the DInSAR-based corresponding optical-based inventories. One may notice that the number of inventoried active phenomena is higher in the optical than in the DInSAR tally. The reasons for these differences are reviewed in more detail in Section 5 (Discussion).

Considering the SAR coverage, the DInSAR inventory shows numbers closer to one based on optical data in areas where two trajectories are available (ascending and descending). The Ansilta Basin, which is not covered by two SAR trajectories, presents the greatest differences compared to the optical inventory. The rest of the basins, on average, show $41 \%$ less detected active rock glaciers with respect to the optical inventory. In particular, the basins of Los Patos and Cuevas-Vacas have the highest ascending/descending coverage and show the smallest differences with respect to the optical 
inventory. The opposite occurs in the Castaño, Calingasta, and Tupungato basins. Last, the Blanco river basin is a particular case. It has wide coverage from both ascending and descending trajectories, but a relatively high difference with respect to the optical inventory.

Table 3. Detected active rock glaciers with DInSAR and optical techniques in the different studied basins. The acronym meanings are: ARG: Active Rock Glacier; DCG-RG: Debris-covered Glacier-Rock Glacier.

\begin{tabular}{|c|c|c|c|c|}
\hline \multicolumn{5}{|c|}{ Amount of Active Rock Glaciers (ARG) } \\
\hline \multirow[t]{2}{*}{ Basin } & \multicolumn{2}{|c|}{ ARG } & \multirow{2}{*}{$\begin{array}{c}\text { DCG-RG } \\
\text { Optical }\end{array}$} & \multirow{2}{*}{$\begin{array}{c}\text { \% Difference } \\
\text { DInSAR-Optica }\end{array}$} \\
\hline & DInSAR & Optical & & \\
\hline Calingasta & 86 & 141 & 11 & $-43.4 \%$ \\
\hline Ansilta & 36 & 133 & 6 & $-74.1 \%$ \\
\hline Blanco & 540 & 884 & 20 & $-40.2 \%$ \\
\hline Los Patos & 339 & 501 & 35 & $-36.7 \%$ \\
\hline Castaño & 226 & 380 & 6 & $-41.4 \%$ \\
\hline Cuevas-Vacas & 130 & 189 & 17 & $-36.7 \%$ \\
\hline Tupungato & 167 & 294 & 38 & $-49.7 \%$ \\
\hline Total & 1524 & 2522 & 133 & \\
\hline
\end{tabular}

Figure 4A shows light blue and red polygonal shapes (optical image) in which both are rock glaciers identified as active with geomorphological criteria (National Glacier Inventory, IANIGLA-CCT), while the red and black polygons are the active and inactive rock glaciers identified with DInSAR data (Figure 4B-F). These vectorial files are superimposed on optical satellite imagery (Figure 4A) and five different interferograms (Figure 4B-F). The images correspond to the central sector of the Blanco River basin $\left(31^{\circ} 48^{\prime} 238.21^{\prime \prime} \mathrm{S}-70^{\circ} 10^{\prime} 01.46^{\prime \prime} \mathrm{W}\right)$, which has large regions with inactive and fossil rock glaciers and some active rock glaciers in degradation, especially in its northern sector [54]. It is worth noting that in a small portion of the basin, out of the 14 rock glaciers identified as active in the optical inventory, only a little less than half (six) show evidence of movement in the interferograms.

The interferograms mainly cover the summer and autumn seasons and have a different time lapse. Some aspects of the results in the different interferograms are worth highlighting. First, there are small differences in the interpretation of the movement according to ascending or descending orbit. Second, in general, both summer and autumn active rock glaciers display movement, but some bodies exhibit no movement in autumn. Third, in the shortest time lapse (six days), the perceptible movement is lower than for the longer time intervals. Only two active rock glaciers present movement in the six-day interval. Last, sectors with movement and others without movement have been observed in the same landform. This is very common in active rock glaciers due to their dynamics. 

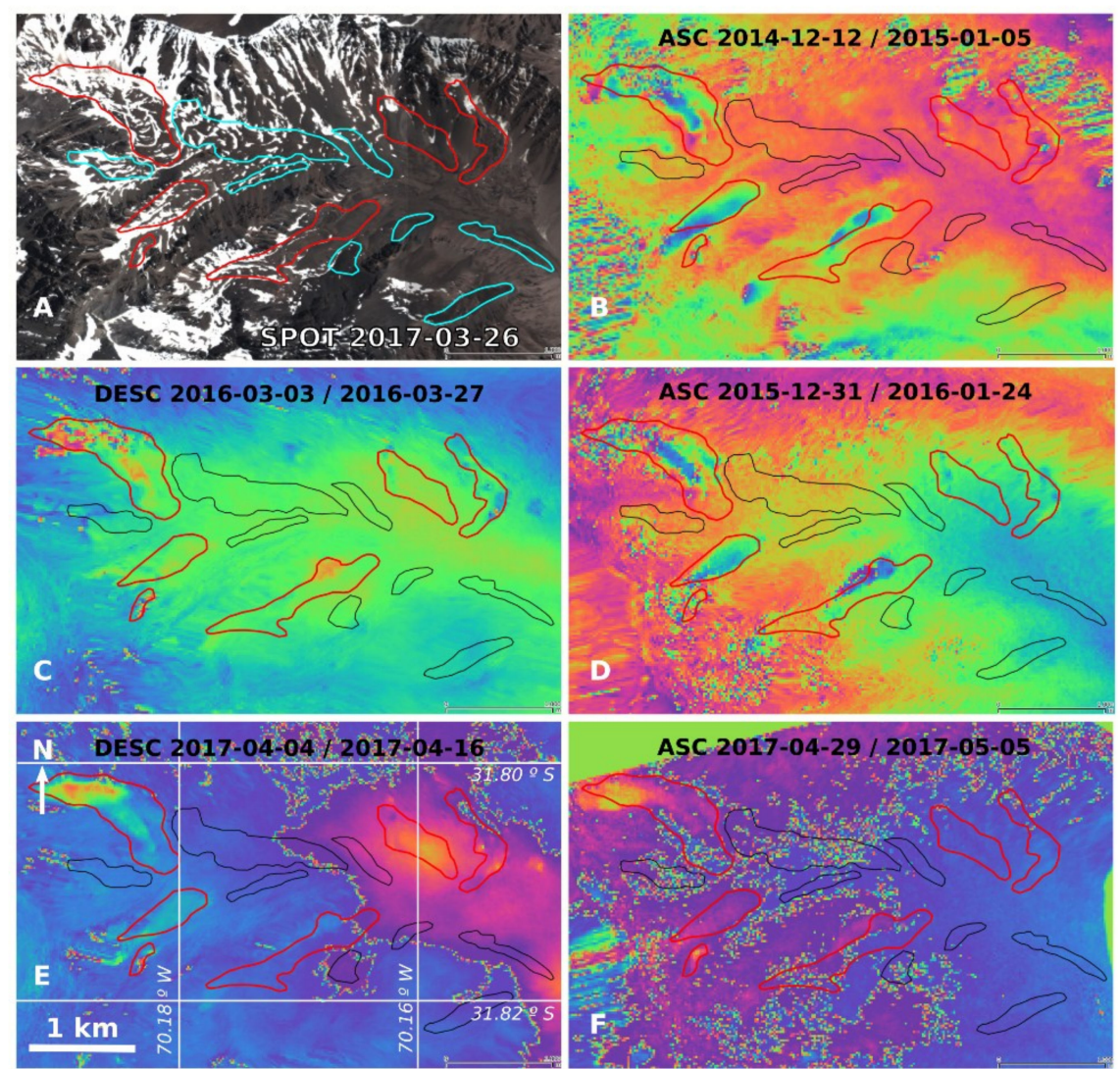

Figure 4. Results of different criteria applied to DInSAR and Optical data to determine the degree of activity. The rock glaciers identified as active in both techniques (DInSAR and Optical) are represented by red polygons, while light blue and black polygons indicate active and inactive rock glaciers according to the geomorphological or DInSAR technique, respectively. The results of both criteria were plotted in an optical image (A-upper left) and in five (ascending and descending) interferograms (B-F). No phase changes are observed in some rock glaciers classified as active according to geomorphological criteria. Interferograms B and D (late spring to early summer) show the highest degree of activity, while C and E interferograms (late summer to early autumn) have a lower degree of activity. The interferogram with the shortest temporal baseline (F) is the one with the least amount of creeping rock glaciers.

\subsection{Analysis of the Spatial Structural Model}

The $p$-value resulting from the analysis of variance (ANOVA) $-<2.2 \mathrm{e}-16-$, indicates significant differences between the mean elevations per basin, confirming the influence of the basin factor (Figure 5A).

Global trend analysis in the structural model was carried out through graphic analysis. Figure 3 discretely shows a growing trend of rock glacier elevation toward the east. This analysis has been complemented with a dispersion diagram of the elevation with respect to the geographical position (latitude and longitude) (Figure 5B). This diagram allows us to assume the shape of an inclined plane determined by a polynomial equation for the global trend, whose greatest slope is found in the west-east direction.

For the second stochastic component of the structural model $\delta(\mathrm{s})$, the omnidirectional and directional semivariograms were calculated at $0^{\circ}, 45^{\circ}, 90^{\circ}$, and $135^{\circ}$ (Figure 6).

Spatial autocorrelation at elevations up to an approximate distance of 1.0 (approximately $100 \mathrm{Km}$ ) has been confirmed in the omnidirectional semivariogram, with a significant micro-variability at minimum distances of the order of $\pm 200 \mathrm{~m}$. The directional semivariograms reveal the direction $90^{\circ}$ as the lowest micro-variability $(178 \mathrm{~m})$. This is of greater autocorrelation or less variability between the elevations of the rock glaciers (Figure 6). 

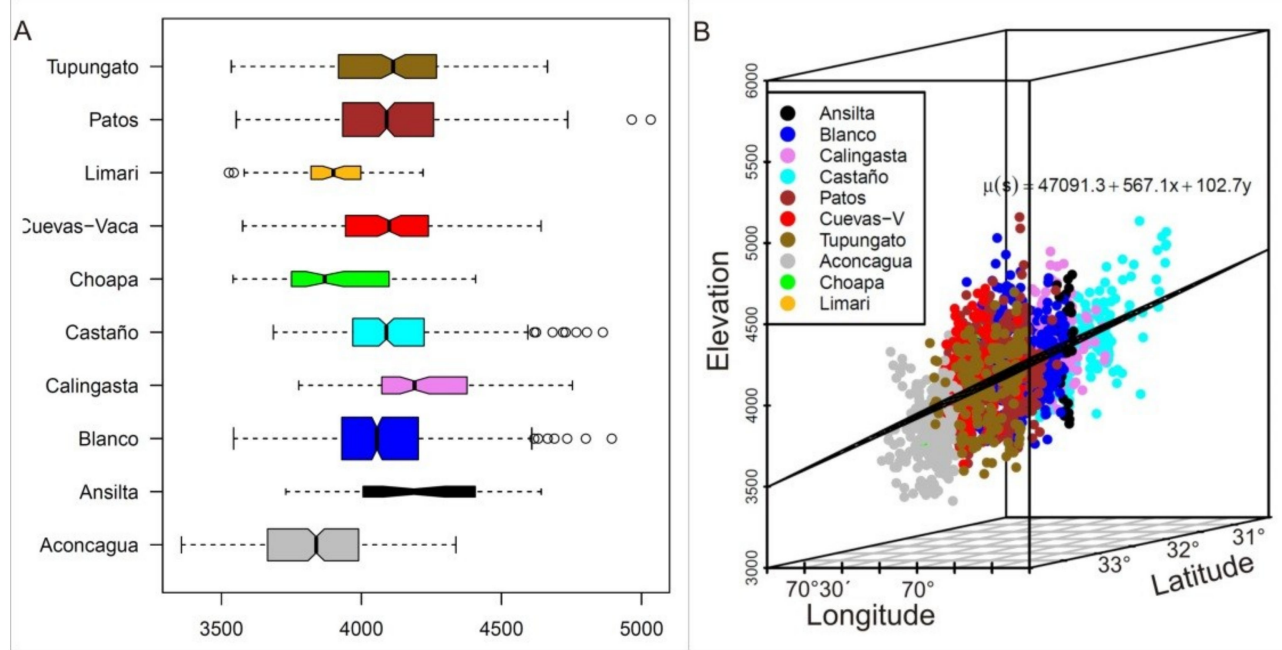

Figure 5. (A) Box and whisker plot considering the elevations of rock glaciers by basin. The width of the boxes is proportional to the amount of rock glaciers per basin. (B) Scatter diagram of elevation with respect to latitude and longitude.

The directional semivariograms per basin show some differences with respect to general behavior, since not all basins have spatial autocorrelation in the four main directions. This is the case of the Tupungato, Patos, Choapa, and Castaño basins which, in at least one direction, do not have anisotropy. The directions where there is autocorrelation vary according to the basin and have a maximum range of 0.1 to $0.2(10$ to $20 \mathrm{Km})$. In addition, some basins display lower microvariability, reaching values of up to $130 \mathrm{~m}$ (Figure 6).
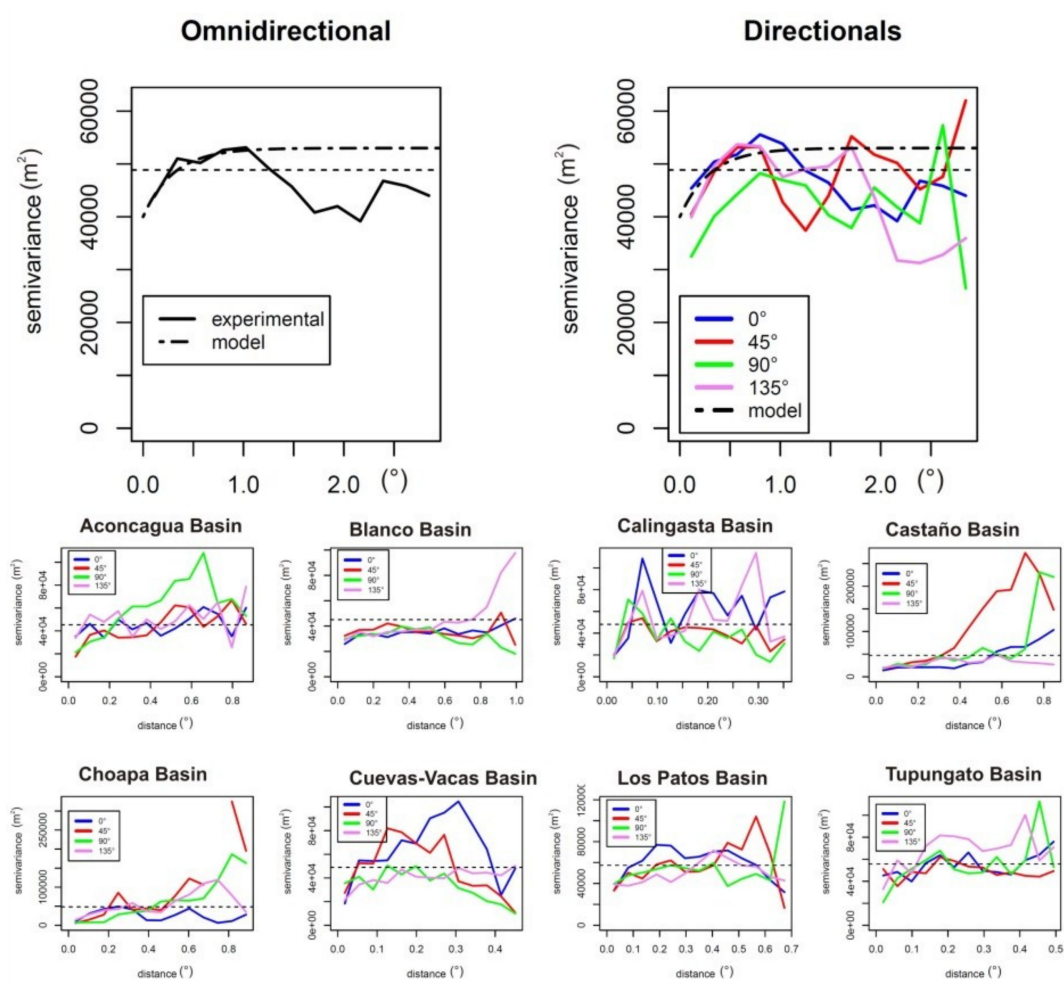

Figure 6. Omnidirectional and directional semivariograms of the whole study area and differentiated according to the basin. The $\mathrm{x}$-axis in all the graphs indicates the distance expressed in decimal degrees. Note that in the latitudinal direction, one-degree represents $111.3 \mathrm{Km}$, while in the longitudinal direction, this relationship changes. At $30^{\circ}$ and $35^{\circ}$ south latitude, one-degree represents 96.4 and $91.2 \mathrm{Km}$, respectively. 


\section{Discussion}

This work has shown the potential of the DInSAR technique with Sentinel-1 data as a tool for mapping rock glaciers and assessing their state of activity. The main result is the regional inventory of active rock glaciers of the Argentine and Chilean Dry Andes region. This is the first time that the DInSAR technique has been used for this purpose in this area. The results have also highlighted the potential of the integration of radar and optical techniques to obtain more complete and reliable inventories. This can be more evident by fully exploiting the temporal sampling of Sentinel- 1 and Sentinel-2 satellites.

The comparison of DInSAR and Optical-based inventories has shown differences in the number of inventoried active rock glaciers. This can be explained by three main reasons.

The first one, as shown before in this work (Section 4.1), is due to an overestimation during the classification of the degree of activity according to geomorphological criteria. As shown in Figure 4, there are rock glaciers that have been classified as active in the optical inventory. However, they are considered inactive if the interferograms do not show evidence of movement. According to the NGI carried out by IANIGLA, only 15\% of the rock glaciers of the Blanco River basin are inactive. However, this basin has large areas of inactivity, especially in its northern sector [70]. In addition, the opposite situation can also occur. For example, Delaloye et al. [71] identified a rock glacier that looked inactive according to geomorphological criteria, but had very slow movements $(0.02-0.05 \mathrm{~m} /$ year $)$ in its lower half. Situations like these may influence an underestimation of the amount of active rock glaciers. No such situation was recorded in our work. All rock glaciers identified as active had also been identified as active in the optical inventory.

The second reason is that an interferogram is a picture of a rock glacier's activity during the period between the two Sentinel-1 acquisition times. In this work, we used 16 interferograms with different temporal baselines and hence with different minimum detectable movement. Therefore, all active rock glaciers with annual displacements below this minimum (e.g., $4.2 \mathrm{~cm} /$ year for 24-day interferograms) were not detected as active. In addition, there may be seasonal variations in the superficial velocities not detected by the temporal ranges included in the interferograms. Kaab et al. [22] established that the deformation magnitudes of these landforms can change at different temporal scales, ranging from millennia to seasonal, sub-seasonal, or daily.

The third reason is due to the SAR system geometry, which is an LOS system. Although this limiting factor can be reduced by using both ascending and descending satellite trajectories, there is still a range of moving slopes, mainly north or south-oriented, where the sensitivity of the DInSAR technique is very low. However, the range of non-detectable moving slopes can be wider if any of the trajectories are not available.

The authors conclude that the first is the most important reason, and could have been checked in an area of the Blanco River basin (Figure 4). The second reason can be significantly improved by adding new interferograms to the network, even though it has significantly influenced the obtained results.

Previously-existing inventories in the region were based on airborne and satellite optical data and a few field surveys $[1-4,24,70]$. In these inventories, the state of rock glacier activity was stated based on geomorphological criteria as the inclination of the frontal slope, the angle of the upper part of the rock glacier front, the organization of the fine debris layers, the presence or absence of vegetation, and the degree of development of furrows and ridges over the rock glacier surface, among others [72,73]. However, one of the main weaknesses of such criteria is that they are based on subjective assessments, and thus lack quantitative measurement of their dynamics. In some cases, this can lead to erroneous interpretations, as in cases in which the evidence of a change in the rock glacier's degree of activity, for example, surface degradation or weathering, appears after some time has passed.

In the specific case of rock glaciers, the classification requires previous discrimination between rock glaciers and other landforms, and then a classification as a function of their state of activity (active, inactive, or relict rock glaciers). Geomorphological analysis does not always give a straightforward view of this aspect. For example, the discrimination between an active/inactive rock glacier or an inactive/relict rock 
glacier is very difficult, especially in transition areas. In addition, it is possible that some rock glaciers show no signs of permafrost degradation yet, although these processes are occurring. In this context, Schmid et al. [74] proposed the use of two independent experts to carry out the classification and only including in the inventory those landforms detected by both. The work concludes that this approach significantly reduces the uncertainties in the inventory and classification of landforms.

Other works propose solving the ambiguity between active and inactive rock glaciers by considering only two different categories: intact rock glaciers [68], including both active and inactive in the same category; and the relict rock glaciers [1,3,74]. However, this approach avoids the discrimination between active and inactive rock glaciers, which is key given that the climatic, paleoclimatic, geomorphologic, and hydrologic significance is different for each case [24]. On one hand, an active rock glacier is in thermal equilibrium with the environment. It conserves its ice and its active layer acts as a water regulator, keeping the water in a solid state in winter and releasing it in summer. On the other hand, an inactive rock glacier is not in thermal equilibrium with the environment and slowly loses its internal ice as it melts, introducing new water to the active part of hydrologic cycle. Furthermore, both Roer and Nyenhuis [9] and Azócar [10] have shown that the geomorphological, geomorphometric, and environmental or ecological parameters are more useful to discriminate between active or relict rock glaciers than between active or inactive glaciers. Moreover, some of the parameters used are in situ measurements, an important constraint for regional applications.

In this context, the measurement of the surface movement of rock glaciers becomes very important for their classification. However, field techniques are difficult for regional studies because of the high economic cost, time constraints, and inaccessibility to many places. In this sense, the use of active remote sensors is fundamental for regional geocryological studies. Another option used is the cross-correlation technique based on optical satellite images. However, this presents difficulties at lower scales for regional studies, since it requires satellite images of a high spatial resolution that are subjected to very thorough orthorectification and corregistered processing. Likewise, it must cover sufficiently significant periods, again requiring greater economic and human efforts [5,75].

Several surveys have tried to identify the topo-climatic variables and their degree of influence on the development of rock glaciers $[30,70,76]$. But, as this work does not aim to identify these parameters or their relative importance, only elevation has been considered as a topographical variable to elucidate the influence on true active rock glacier distribution. Elevation or altitude can be considered as an indirect indicator (proxy) of an influencing factor. This means that the distribution of rock glaciers depends on another factor that is highly correlated with the obvious one. The dependence of rock glacier distribution on elevation results mainly from its dependence on air temperature [77].

In this work, we performed a statistical analysis of the relation between the elevation of active rock glaciers and their geographic position. It was observed that there is an increase in the minimum height of occurrence towards the east and north, but the slope of the plane to the east is greater than to the north. This increase is fairly well assimilated to the behavior of the $0{ }^{\circ} \mathrm{C}$ isotherm, which would indicate the lower limit of the occurrence of current active rock glaciers.

Although the MAAT is a variable that affects the presence of active rock glaciers, there are other variables and ground properties, such as aspect, solar radiation, lithology, and thermal conductivity, among others, that locally have an influence on the occurrence of these landforms. This is verified in the high spatial micro-variability (between 130 and $200 \mathrm{~m}$ ) over short distances of the semi-variograms in all of their directions. Considering a normal thermal gradient for mountainous regions between 0.6 and $0.7{ }^{\circ} \mathrm{C} / 100 \mathrm{~m}$, this spatial micro-variability represents approximately $1.4{ }^{\circ} \mathrm{C}$. This means that the occurrence of nearby active rock glaciers is influenced by local topo-climatic factors as well as air temperature.

In Argentina, our work reveals minimum heights of rock glacier occurrence of approximately 3500 m.a.s.l. between the latitudes $33^{\circ} 4^{\prime}$ and $31^{\circ} 3^{\prime}$ south. The maximum elevations do not display much variability, with an approximate value of 4700 m.a.s.l., except near Mercedario Hill (6720 m.a.s.l.) and the area around $30^{\circ} 40^{\prime} \mathrm{S}$ of latitude, where the maximum heights reach values near 5000 m.a.s.l. 
These results are consistent with more detailed studies conducted in the area, as Tombotto et al. [20] on $32^{\circ} 54^{\prime}-33^{\circ} 1^{\prime}$ south latitude over El Salto and Morenas Coloradas active rock glaciers with minimum heights of 3600 and 3400 m.a.s.l. respectively and; Croce and Milana [78] established a minimum height of 4000 m.a.s.l. for the El Paso active rock glacier $\left(30^{\circ} 13^{\prime}\right)$. The preliminary rock glacier inventory at $30^{\circ} \mathrm{S}$ shows a minimum height of 3651 m.a.s.1. [14], while Esper Angillieri [4] indicated a minimum occurrence of active rock glaciers at 3284 m.a.s.l. to $30^{\circ} 30^{\prime} \mathrm{S}$ latitude.

This last minimum altitude value of active rock glacier occurrence is relatively low compared to our values and with the $0{ }^{\circ} \mathrm{C}$ isotherm, possibly because it is a smaller landform or has a surface velocity below our thresholds ( 2 ha and $2.2 \mathrm{~cm} /$ year, respectively). It may be located within a local environment that allows for its development or conservation. Additionally, a possible error in the identification of this landform as active according to geomorphological criteria should not be ruled out.

On the Chilean side, previous studies also agree with our results. In the Cajon de la Casa de Piedra sub-basin (several dozen kilometers south of our study area), Brenning [24] detected active rock glaciers at 3000 m.a.s.1., and in Los Andes de Santiago (33-34 ${ }^{\circ}$ S), Brenning and Trombotto [3] identified active rock glaciers close to 3000 m.a.s.l., interpreting that these bodies represent past periglacial conditions, as these landforms are more frequently found above 3500 m.a.s.l. in that area. Milana and Güell [79] carried out geophysical studies on two rock glaciers, both at an altitude of 4200 m.a.s.l. in the Elqui river basin. Bodin et al. [80] described an active rock glacier in the Laguna Negra basin at 3200 m.a.s.l., while in their regional study on rock glaciers of the Arid Andes of Chile (27-33 ${ }^{\circ} \mathrm{S}$ latitude), Azócar and Brenning [58] indicated a minimum height with an abundant amount of active rock glaciers at 3500 m.a.s.1. at $33^{\circ}$ and 4750 m.a.s.l. at $27^{\circ} \mathrm{S}$.

This work demonstrates the potential use of Sentinel-1 DInSAR interferometry to detect active rock glaciers in mountainous areas, which is an important aspect of cryosphere studies. These landforms are considered the main evidence of mountain permafrost and their frontal taluses usually indicate the lower limit for the presence of discontinuous mountain permafrost [80]. Several studies have used rock glaciers together with topographic and climatic indicators to generate models of probable permafrost distribution. However, in most cases, due to the ambiguities in the optical images commented on above, these models are generated based on a simple classification of the rock glaciers, and include both active and inactive landforms in the same class, as in [3]. However, even though an inactive rock glacier conserves a part of its internal ice, it is not affected by creeping and thus represents a degraded permafrost.

Further work will focus on the use of multitemporal DInSAR to detect small movements ( $\mathrm{mm} /$ year) in rock glaciers. This type of analysis will provide complementary information on the seasonal variability of displacement rates. This is key information for bodies with very small deformation rates but with signs of geomorphological activity. Moreover, continuously updating the obtained inventory by analysing each new pair of images can suppose a significant improvement of the obtained results and a potential tool to better understand the dynamics of the landforms in the region. In this sense, further research could focus on the investigation of automatic or semi-automatic methods to detect active landforms.

\section{Conclusions}

A total amount of 2116 rock glaciers have been classified as active in the area of study during the monitored period. The level of activity ranges from $2.2 \mathrm{~cm} /$ year to $170 \mathrm{~cm} /$ year. Moreover, the high spatial variability of these landforms (between 130 and $200 \mathrm{~m}$ ) observed in the semi-variograms confirmed the influence of different variables on the rock glacier occurrence.

This work has shown the potential of the Sentinel-1 Differential Synthetic Aperture Radar (DInSAR) technique for active rock glacier inventorying, which is an important parameter for assessing the health of mountain basin hydrological systems. It provides an efficient, fast, and low-cost way to generate such inventories at the regional scale and in areas of difficult access. Compared to optical techniques, it provides a reliable assessment of the state of activity of the rock glaciers that is more 
independent from the operator's interpretation. It can provide quantitative measurements of the level of activity depending on deformation rates, as well as the changes on the rock glacier surface. It can be used regardless of the meteorological conditions, and the data have a reasonable resolution and are freely available. Moreover, it is expected that the increase of Sentinel-1 data available in the area of study will enable researchers to augment the period covered and in so doing, detect different levels of rock glacier activity in different seasonal periods.

The study has also shown some limitations that must be underlined. First, it does not provide an exhaustive inventory given that the sensitivity to the activity strongly depends on the main slope direction being the minimum in the north/south oriented rock glaciers. However, thanks to the Sentinel-1 acquisition frequency and orbital trajectories available, this limitation can be significantly minimized. Secondly, it only provides a picture of the covered period. This means that it only provides information of the rock glaciers that have been active during the monitored period, but it does not provide any information about the ones that have not been active in the same period. In this context, it is expected that the increase of the dataset in the near future will help to improve this. Thirdly, in the high mountain areas, the presence of snow can cause a loss of information. However, from this work, we have seen that it is also possible to measure activity in snowy areas if the snow conditions do not change between the interferometric acquisitions. Finally, it is worth noting that even the active/inactive landform classification is carried out without any external data, whereas the discrimination between rock glaciers and other landforms requires auxiliary data. The use of radar images in conjunction with optical images makes it possible to obtain more complete and reliable active rock glacier inventories.

Author Contributions: Formal analysis, C.D.V., G.T.B., and M.M.; Investigation, C.D.V.; Resources, G.T.B.; Writing—original draft, G.T.B., A.P.F., and O.M.; Writing—review \& editing, C.D.V.

Funding: This research received no external funding. The APC was funded by Technological Center of Telecommunications of Catalonia (CTTC).

Acknowledgments: The authors acknowledge National Commission of Space Activities (CONAE) for the SPOT 6 and 7 images. In addition, the Bec.AR scholarship program is thanked for allowing the training of Guillermo Tamburini at the CTTC, Barcelona, Spain.

Conflicts of Interest: The authors declare no conflict of interest.

\section{References}

1. Azócar, G.F.; Brenning, A.; Bodin, X. Permafrost distribution modelling in the semi-arid Chilean Andes. Cryosphere 2017, 11, 877-890. [CrossRef]

2. Corte, A.E.E.; Corte, L.E.A.E.; Espizua, L.E. Inventario de glaciares de la cuenca del río Mendoza. In Technical Report, Consejo Nacional de Investigaciones Científicas y Técnicas; Instituto Argentino de Nivología y Glaciología: Mendoza, Argentina, 1981.

3. Brenning, A.; Trombotto, D. Logistic regression modelling of rock glacier and glacier distribution: Topographic and climatic controls in the semi-arid Andes. Geomorphology 2006, 81, 141-154. [CrossRef]

4. Esper Angillieri, M.Y.E. A preliminary inventory of rock glaciers at $30^{\circ} \mathrm{S}$ latitude, cordillera frontal of San Juan, Argentina. Quat. Int. 2009, 195, 151-157. [CrossRef]

5. Wang, X.; Liu, L.; Zhao, L.; Wu, T.; Li, Z.; Liu, G. Mapping and inventorying active rock glaciers in the northern Tien Shan of China using satellite SAR interferometry. Cryosphere 2017, 11, 997-1014. [CrossRef]

6. Barboux, C.; Strozzi, T.; Delaloye, R.; Wegmuller, U.; Collet, C. Mapping slope movements in alpine environments using Tterrasar-X interferometric methods. ISPRS J. Photogramm. Remote Sens. 2015, 109, 178-192. [CrossRef]

7. Callegari, M.; Cantone, A.; Cuozzo, G.; Defilippi, M.; Notarnicola, C.; Pasquali, P.; Riccardi, P.; Seppi, R.; Seppi, S.; Zucca, F. Combining Radarsat-2 and Cosmo-Skymed data for alpine permafrost deformation monitoring. In Proceedings of the IEEE International Geoscience and Remote Sensing Symposium (IGARSS), Milan, Italy, 26-31 July 2015; pp. 5260-5263.

8. Liu, L.; Millar, C.I.; Westfall, R.D.; Zebker, H.A. Surface motion of active rock glaciers in the Sierra Nevada, California, USA: Inventory and a case study using InSAR. Cryosphere 2013, 7, 1109. [CrossRef]

9. Roer, I.; Nyenhuis, M. Rockglacier activity studies on a regional scale: comparison of geomorphological mapping and photogrammetric monitoring. Earth Surf. Process. Landf. 2007, 32, 1747-1758. [CrossRef] 
10. Azocar, G. Modeling of Permafrost Distribution in the Semi-Arid Chilean Andes. Master's Thesis, University of Waterloo, Waterloo, ON, USA, 2014.

11. Barboux, C.; Delaloye, R.; Lambiel, C. Inventorying slope movements in an Alpine environment using DInSAR. Earth Surf. Process. Landf. 2014, 39, 2087-2099. [CrossRef]

12. Kenyi, L.W.; Kaufmann, V. Estimation of rock glacier surface deformation using SAR interferometry data. IEEE Trans. Geosci. Remote Sens. 2003, 41, 1512-1515. [CrossRef]

13. Rott, H.; Siegel, A. Analysis of mass movements in alpine terrain by means of SAR interferometry. In Proceedings of the IEEE 1999 International Geoscience and Remote Sensing Symposium, Hamburg, Germany, 28 June-2 July 1999.

14. Kenyi, L.; Kaufmann, V. Detection and quantification of rock glacier deformation using ERS D-InSAR data. In Proceedings of the ERS-Envisat Symposium, Gothenburg, Sweden, 16-20 October 2000.

15. Nagler, T.; Mayer, C.; Rott, H. Feasibility of DINSAR for mapping complex motion fields of Alpine ice-and rock-glaciers. In Retrieval of Bio-and Geo-Physical Parameters from SAR Data for Land Applications; European Space Agency: Paris, France, 2002; Volume 475, pp. 377-382.

16. Rignot, E.; Hallet, B.; Fountain, A. Rock glacier surface motion in Beacon Valley, Antarctica, from synthetic-aperture radar interferometry. Geophys. Res. Lett. 2002, 29, 17. [CrossRef]

17. Lilleøren, K.S.; Etzelmüller, B.; Gärtner-Roer, I.; Kääb, A.; Westermann, S.; Guðmundsson, Á. The distribution, thermal characteristics and dynamics of permafrost in Tröllaskagi, northern Iceland, as inferred from the distribution of rock glaciers and ice-cored moraines. Permafr. Periglac. Process. 2013, 24, 322-335. [CrossRef]

18. Necsoiu, M.; Onaca, A.; Wigginton, S.; Urdea, P. Rock glacier dynamics in Southern Carpathian Mountains from high-resolution optical and multi-temporal SAR satellite imagery. Remote Sens. Environ. 2016, 177, $21-36$. [CrossRef]

19. Strozzi, T.; Kääb, A.; Frauenfelder, R. Detecting and quantifying mountain permafrost creep from in situ inventory, space-borne radar interferometry and airborne digital photogrammetry. Int. J. Remote Sens. 2004, 25, 2919-2931. [CrossRef]

20. Trombotto, D.; Buk, E.; Hernández, J. Rock Glaciers in the Southern Central Andes (Approx. 33-34 s), Cordillera frontal, Mendoza, Argentina; Bamberger Geographische Schriften; University of Bamberg Press: Bamberg, Germany, 1999; Volume 19, pp. 145-173.

21. Barsch, D. Permafrost creep and rock glaciers. Permafr. Periglac. Process. 1992, 3, 175-188. [CrossRef]

22. Kääb, A.; Frauenfelder, R.; Roer, I. On the response of rock glacier creep to surface temperature increase. Glob. Planet. Chang. 2007, 56, 172-187. [CrossRef]

23. Schrott, L. Some geomorphological-hydrological aspects of rock glaciers in the Andes (San Juan, Argentina). Zeitschrift Fur Geomorphologie 1996, Suppl.-Bd. 104, 161-173.

24. Brenning, A. Geomorphological, hydrological and climatic significance of rock glaciers in the Andes of central Chile (33-35 s). Permafr. Periglac. Process. 2005, 16, 231-240. [CrossRef]

25. Janke, J.R.; Bellisario, A.C.; Ferrando, F.A. Classification of debris-covered glaciers and rock glaciers in the Andes of central Chile. Geomorphology 2015, 241, 98-121. [CrossRef]

26. Bodin, X.; Thomas, E.; Liaudat, D.T.; Vivero, S.; Pitte, P. Rock glacier activity and distribution in the semi-arid Andes of Chile and Argentina detected from dInSAR. In Proceedings of the International Conference on Permafrost, Potsdam, Germany, 20-24 June 2016.

27. Janousek, F.N.M.; Fontana, P.; Capone, A.A.; Sosa, G.J.; Euillades, P.A.; Euillades, L.D. Preliminary analysis of the status of rock glaciers using SAR images. In Proceedings of the 2017 XVII Workshop on Information Processing and Control (RPIC), Mar de Plata, Argentina, 20-22 September 2017; pp. 1-5.

28. Lliboutry, L. Glaciers of Chile and Argentina; Geological Survey Professional Paper; USGS: Reston, VA, USA, 1998; p. 1103.

29. Gruber, S.; Haeberli, W. Mountain Permafrost; Springer: Berlin, Germany, 2009; pp. 33-44.

30. Esper Angillieri, M.Y. Permafrost distribution map of San Juan Dry Andes (Argentina) based on rock glacier sites. J. S. Am. Earth Sci. 2017, 73 (Suppl. C), 42-49. [CrossRef]

31. INDEC (Instituto Nacional de Estadística y Censo). 2010. Available online: http://www.sig.indec.gov.ar/ censo2010/ (accessed on 1 September 2017).

32. INE (Instituto Nacional de Estadísticas). 2017. Available online: http://palma.ine.cl/demografia/menu/ genera/indice.aspx (accessed on 24 August 2017). 
33. Milana, J.P. Predicción de caudales de ríos alimentados por deshielo mediante balances de energía: Aplicaci'on en los Andes centrales, Argentina. Revista de la Asociación Argentina de Sedimentología 1998, 5, 53-69.

34. Hearnea, R.R.; Donoso, G. Water institutional reforms in Chile. Water Policy 2005, 7, 53-69. [CrossRef]

35. Leiva, J.; Cabrera, G.; Lenzano, L. 20 years of mass balances on the Piloto glacier, las Cuevas river basin, mendoza, Argentina. Glob. Planet. Chang. 2007, 59, 10-16. [CrossRef]

36. Gascoin, S.; Kinnard, C.; Ponce, R.; Macdonell, S.; Lhermitte, S.; Rabatel, A. Glacier contribution to streamflow in two headwaters of the huasco river, dry Andes of Chile. Cryosphere 2011, 5, 1099-1113. [CrossRef]

37. Masiokas, M.H.; Villalba, R.; Luckman, B.H.; Le Quesne, C.; Aravena, J.C. Snowpack variations in the central Andes of Argentina and Chile, 1951-2005: Large-scale atmospheric influences and implications for water resources in the region. J. Clim. 2006, 19, 6334-6352. [CrossRef]

38. Brown Fernández, E.; Saldivia Medina, J.E.; South American Technical Advisory Committee. Informe Nacional Sobre la Gestión del Agua en Chile; Global Water Partnership: Stockholm, Sweden, 2000.

39. Rosegrant, M.W.; Ringler, C.; McKinney, D.C.; Cai, X.; Keller, A.; Donoso, G. Integrated economic-hydrologic water modeling at the basin scale: The Maipo river basin. Agric. Econ. 2000, 24, 33-46.

40. Cai, X.; Rosegrant, M.W.; Ringler, C. Physical and economic efficiency of water use in the river basin: Implications for efficient water management. Water Resour. Res. 2003, 39. [CrossRef]

41. Brenning, A.; Azócar, G.F. Minería y glaciares rocosos: Impactos ambientales, antecedentes pol'iticos y legales, y perspectivas futuras. Revista de Geograf'ia Norte Grande 2010, 47, 143-158. [CrossRef]

42. Stehr, A.; Aguayo, M. Snow cover dynamics in Andean watersheds of Chile $\left(32.0-39.5^{\circ} \mathrm{S}\right)$ during the years 2000-2016. Hydrol. Earth Syst. Sci. 2017, 21, 5111-5126. [CrossRef]

43. Valdés-Pineda, R.; Pizarro, R.; García-Chevesich, P.; Valdés, J.B.; Olivares, C.; Vera, M.; Abarza, A. Water governance in Chile: Availability, management and climate change. J. Hydrol. 2014, 519, $2538-2567$. [CrossRef]

44. Minetti, J.; Vargas, W.; Vega, B.; Costa, M. Las sequias en la pampa húmeda: Impacto en la productividad del maíz. Revista Brasileira de Meteorología 2007, 22, 218-232. [CrossRef]

45. Montecinos, A.; Díaz, A.; Aceituno, P. Seasonal diagnostic and predictability of rainfall in subtropical South America based on tropical pacific SST. J. Clim. 2000, 13, 746-758. [CrossRef]

46. Bolius, D.; Schwikowski, M.; Jenk, T.; Gaggeler, H.W.; Casassa, G.; Rivera, A. A first shallow firn-core record from glaciar la ollada, cerro mercedario, central argentine Andes. Ann. Glaciol. 2006, 43, 14-22. [CrossRef]

47. Corripio, J.; Purves, R.; Rivera, A. Modeling climate change impacts on mountain glaciers and water resources in the central dry Andes. In Darkening Peaks: Glacier Retreat, Science and Society; University of California Press: Berkeley, CA, USA, 2007; pp. 126-135.

48. Núñez, J.; Rivera, D.; Oyarz'un, R.; Arumí, J. Influence of pacific ocean multidecadal variability on the distributional properties of hydrological variables in north-central Chile. J. Hydrol. 2013, 501, 227-240. [CrossRef]

49. González-Reyes, Á.; McPhee, J.; Christie, D.A.; Le Quesne, C.; Szejner, P.; Masiokas, M.H.; Villalba, R.; Muñoz, A.A.; Crespo, S. Spatiotemporal variations in hydroclimate across the Mediterranean Andes $\left(30^{\circ}-37^{\circ} \mathrm{S}\right)$ since the early twentieth century. J. Hydrometeorol. 2017, 18, 1929-1942. [CrossRef]

50. Rutllant, J.; Garreaud, R. Episodes of strong flow down the western slope of the subtropical Andes. Mon. Weather Rev. 2004, 132, 611-622. [CrossRef]

51. Kalthoff, N.; Bischoff-Gauß, I.; Fiebig-Wittmaack, M.; Fiedler, F.; Thürauf, J.; Novoa, E.; Pizarro, C.; Castillo, R.; Gallardo, L.; Rondanelli, R.; et al. Mesoscale wind regimes in Chile at 30 S. J. Appl. Meteorol. 2002, 41, 953-970. [CrossRef]

52. Strecker, M.; Alonso, R.; Bookhagen, B.; Carrapa, B.; Hilley, G.; Sobel, E.; Trauth, M. Tectonics and climate of the southern central Andes. Annu. Rev. Earth Planet. Sci. 2007, 35, 747-787. [CrossRef]

53. Jenk, T.; Graesslin-Ciric, A.; Tobler, L.; Gäggeler, H.; Morgenstern, U.; Casassa, G.; Luthi, M.; Schmitt, J.; Eichler, A.; Schwikowski, M. The Mercedario ice core-an excellent archive for enso reconstruction. In Proceedings of the EGU General Assembly Conference Abstracts, Vienna, Austria, 12-17 April 2015.

54. Schrott, L. Global solar radiation, soil temperature and permafrost in the central Andes, Argentina: A progress report. Permafr. Periglac. Process. 1991, 2, 59-66. [CrossRef] 
55. Falvey, M.; Garreaud, R.D. Regional cooling in a warming world: Recent temperature trends in the southeast pacific and along the west coast of subtropical South America (1979-2006). J. Geophys. Res. Atmos. 2009. [CrossRef]

56. Poblete, A.G.; Minetti, J.L. Influye el calentamiento global en la disminución de las nevadas en los Andes Áridos. Revista Universitaria de Geografía 2017, 26, 11-29.

57. Pellicciotti, F.; Ragettli, S.; Carenzo, M.; McPhee, J. Changes of glaciers in the Andes of Chile and priorities for future work. Sci. Total Environ. 2014, 493, 1197-1210. [CrossRef] [PubMed]

58. Azócar, G.; Brenning, A. Hydrological and geomorphological significance of rock glaciers in the dry Andes, Chile (27-33 s). Permafr. Periglac. Process. 2010, 21, 42-53. [CrossRef]

59. Haeberli, W.; Noetzli, J.; Arenson, L.; Delaloye, R.; Gärtner-Roer, I.; Gruber, S.; Phillips, M. Mountain permafrost: Development and challenges of a young research field. J. Glaciol. 2010, 56, 1043-1058. [CrossRef]

60. Bamler, R.; Hartl, P. Synthetic aperture radar interferometry. Inverse Probl. 1998, 14, R1-R54. [CrossRef]

61. Barra, A.; Monserrat, O.; Mazzanti, P.; Esposito, C.; Crosetto, M.; Scarascia Mugnozza, G. First insights on the potential of Sentinel-1 for landslides detection. Geomat. Nat. Hazards Risk 2016, 7, 1874-1883. [CrossRef]

62. Barra, A.; Solari, L.; Béjar-Pizarro, M.; Monserrat, O.; Bianchini, S.; Herrera, G.; Crosetto, M.; Sarro, R.; González-Alonso, E.; Mateos, R.M.; et al. A Methodology to Detect and Update Active Deformation Areas Based on Sentinel-1 SAR Images. Remote Sens. 2017, 9, 1002. [CrossRef]

63. Huang, Q.; Crosetto, M.; Monserrat, O.; Crippa, B. Displacement monitoring and modelling of a high-speed railway bridge using C-band Sentinel-1 data. ISPRS J. Photogramm. Remote Sens. 2017, 128, $204-211$. [CrossRef]

64. Franceschetti, G.; Lanari, R. Synthetic Aperture Radar Processing; CRC Press: Boca Raton, FL, USA, 1999.

65. ESA. ESA Copernicus Open Access Hub. 2017. Available online: https://scihub.copernicus.eu/ (accessed on 20 October 2017).

66. Crosetto, M.; Monserrat, O.; Cuevas, M.; Crippa, B. Spaceborne differential SAR interferometry: Data analysis tools for deformation measurement. Remote Sens. 2011, 3, 305-318. [CrossRef]

67. Farr, T.G.; Rosen, P.A.; Caro, E.; Crippen, R.; Duren, R.; Hensley, S.; Seal, D. The shuttle radar topography mission. Rev. Geophys. 2007, 45. [CrossRef]

68. Barsch, D. Rock Glaciers, Indicators for the Permafrost and Former Geoecology in High Mountain Environment, Series in the Physical Environment; Springer: Berlin, Germany, 1996.

69. Quantum, G. Development Team, 2012. In Quantum GIS Geographic Information; 2014; (https:/ / qgis.org).

70. Forte, A.; Villarroel, C.; Esper Angillieri, M. Impact of natural parameters on rock glacier development and conservation in subtropical mountain ranges. Northern sector of the Argentine Central Andes. Cryosphere Discuss. 2016. [CrossRef]

71. Delaloye, R.; Perruchoud, E.; Avian, M.; Kaufmann, V.; Bodin, X.; Hausmann, H.; Ikeda, A.; Kääb, A.; Kellerer-Pirklbauer, A.; Krainer, K.; et al. Recent interannual variations of rock glacier creep in the European Alps. In Proceedings of the 9th International Conference on Permafrost, Fairbanks, AK, USA, 28 June-3 July 2008; Volume 29, pp. 343-348.

72. Martin, E.; Whalley, W.B. Rock glaciers: Part 1: Rock glacier morphology: Classification and distribution. Prog. Phys. Geogr. 1987, 11, 260-282. [CrossRef]

73. Ikeda, A.; Matsuoka, N. Pebbly versus bouldery rock glaciers: Morphology, structure and processes. Geomorphology 2006, 73, 279-296. [CrossRef]

74. Schmid, M.; Baral, P.; Gruber, S.; Shahi, S.; Shrestha, T.; Stumm, D.; Wester, P. Assessment of permafrost distribution maps in the Hindu Kush Himalayan region using rock glaciers mapped in Google Earth. Cryosphere 2015, 9, 2089-2099. [CrossRef]

75. Tamburini Beliveau, G. Magnitudes y Características de los Procesos Geodinámicos en el Ambiente Glacial y Periglacial del Cordón de la Ramada (Andes Centrales Argentinos) Mediante Técnicas de Teledetección. Ph.D. Thesis, FCEIA—Universidad Nacional de Rosario, Rosario, Santa Fe, Argentina, 2017.

76. Johnson, B.G.; Thackray, G.D.; Van Kirk, R. The effect of topography, latitude, and lithology on rock glacier distribution in the Lemhi Range, central Idaho, USA. Geomorphology 2007, 91, 38-50. [CrossRef]

77. Kenner, R.; Magnusson, J. Estimating the effect of different influencing factors on rock glacier development in two regions in the Swiss Alps. Permafr. Periglac. Process. 2017, 28, 195-208. [CrossRef]

78. Croce, F.A.; Milana, J.P. Internal structure and behaviour of a rock glacier in the arid Andes of Argentina. Permafr. Periglac. Process. 2002, 13, 289-299. [CrossRef] 
79. Milana, J.P.; Güell, A. Diferencias mecánicas e hídricas del permafrost en glaciares de rocas glacigénicos y criogénicos, obtenidas de datos sísmicos en el tapado, Chile. Revista de la Asociación Geológica Argentina 2008, 63, 310-325.

80. Bodin, X.; Rojas, F.; Brenning, A. Status and evolution of the cryosphere in the Andes of Santiago (Chile, 33.5 S.). Geomorphology 2010, 118, 453-464. [CrossRef] 